\title{
35. PETROGRAPHY AND MINERALOGY OF VOLCANOGENIC SEDIMENTS FROM DSDP LEG 48, SOUTHWEST ROCKALL PLATEAU, SITES 403 AND 404
}

\author{
R.K. Harrison, R.W. O'B Knox, and A.C. Morton \\ with contributions by R.J. Merriman and C.W. Wheatley, Institute of Geological Sciences, London, England
}

\begin{abstract}
Quaternary, middle Eocene, lower Eocene and Paleocene volcanogenic sediments were cored at DSDP Leg 48 Sites 403 and 404, on the rifted southwest margin of the Rockall Plateau. The Paleocene-lower Eocene tuffaceous sequence is thickest $(140 \mathrm{~m})$ at Site 403 , but tuff bands are attenuated and diluted by orthoclastic sediment at Site 404 . Site 403 tuffs are mainly of granule, sand-grade, and silt-grade with sparse lapilli. Glass shards are almost entirely argillized, but sparse unaltered shards with pumice and microlitic lava particles indicate mainly basaltic parent magmas with minor rhyolite. The Paleocene-lower Eocene cores indicate a succession of mainly effusive eruptive events, probably originating in the Reykjanes Ridge, Iceland province. Heavy mineral suites group as amphibole-epidote, diopside-hypersthene, and augite-olivine; they are largely unrelated to the pyroclasts and were derived mainly from metamorphic basement including granulites and amphibolites. Vitroclastic foraminiferal ooze of Quaternary age at Site 404 contains abundant fresh glass shards of basaltic and minor rhyolitic types.

The record of Paleocene to lower Eocene vulcanism greatly extends the lower Tertiary volcanic province of northwest Europe, the North Sea Basins, Iceland, and Greenland into the northeast Atlantic; and correlates widespread magmatism with rifting and subsidence in the North Sea and the major opening of the North Atlantic.
\end{abstract}

\section{INTRODUCTION}

The main objective of Leg 48 drilling on the southwest edge of the Rockall Plateau was to determine the geological evolution of a passive margin in terms of rifting and consequent subsidence. Sites 403 and 404 were located on thick sediments unconformably overlain by thin sediments. The primary study objectives were to determine the nature of the unconformity, the succession of the underlying sediments, and their relation to the rifting and spreading of the crust between Greenland and Rockall Plateau.

After penetrating chalky and foraminiferal oozes ranging from upper to middle Eocene, a hiatus was found above a poorly fossiliferous lower Eocene sequence of volcanogenic siltstones and glauconitic mudstones. The upper Paleocene succession includes conglomerates and lignites, probably representing the top of a deltaic sequence. The lower Eocene probably was deposited in inner shelf depths as a southward prograding wedge, but middle bathyal depths prevailed by the middle Eocene.

The Eocene volcanogenic sequences at Sites 403 and 404 extend into the eastern North Atlantic, the known distribution of lower Eocene volcanics. With those of northwest Europe and the North Sea Basins, they constitute a petrographic province some $2500 \mathrm{~km}$ from east to west. The present samples are compared with Paleocene-Eocene tuffs of the North Sea Basins and northwest Europe together with parental sources and magma types. The latest volcanic episode in the area is shown by fresh vitroclastic ash in the Quaternary cores of Site 404.

\section{PETROGRAPHY}

\section{Samples, Methods, Nomenclature}

On the basis of the shipboard log, we selected 35 core samples from a recorded thickness of 140 meters of Paleocene and lower Eocene volcanogenic sediments at Site 403. The sampling density (Figure 1) is representative of the wide range of volcanogenic lithologies present. We also examined 28 samples from 130 meters of Paleocene and lower Eocene volcanogenic sediments from Site 404. We examined one sample of Quaternary ash; the description of this exceptionally fresh sample is presented after that of the Eocene tuffs.

We prepared thin sections of the samples, where possible, and have appended a note on our preparation technique. We examined the remaining samples by smear slides, and separated and examined heavy minerals from most samples. We made X-ray diffraction analyses of selected samples showing the range of lithologies present, but attempted no extensive study in view of the systematic XRD analyses of Leg 48 cores (Latouche and Maillet, this volume). We conducted chemical analyses by atomic absorption spectroscopy of four samples ranging from tuffs to slightly tuffaceous mudstones. 


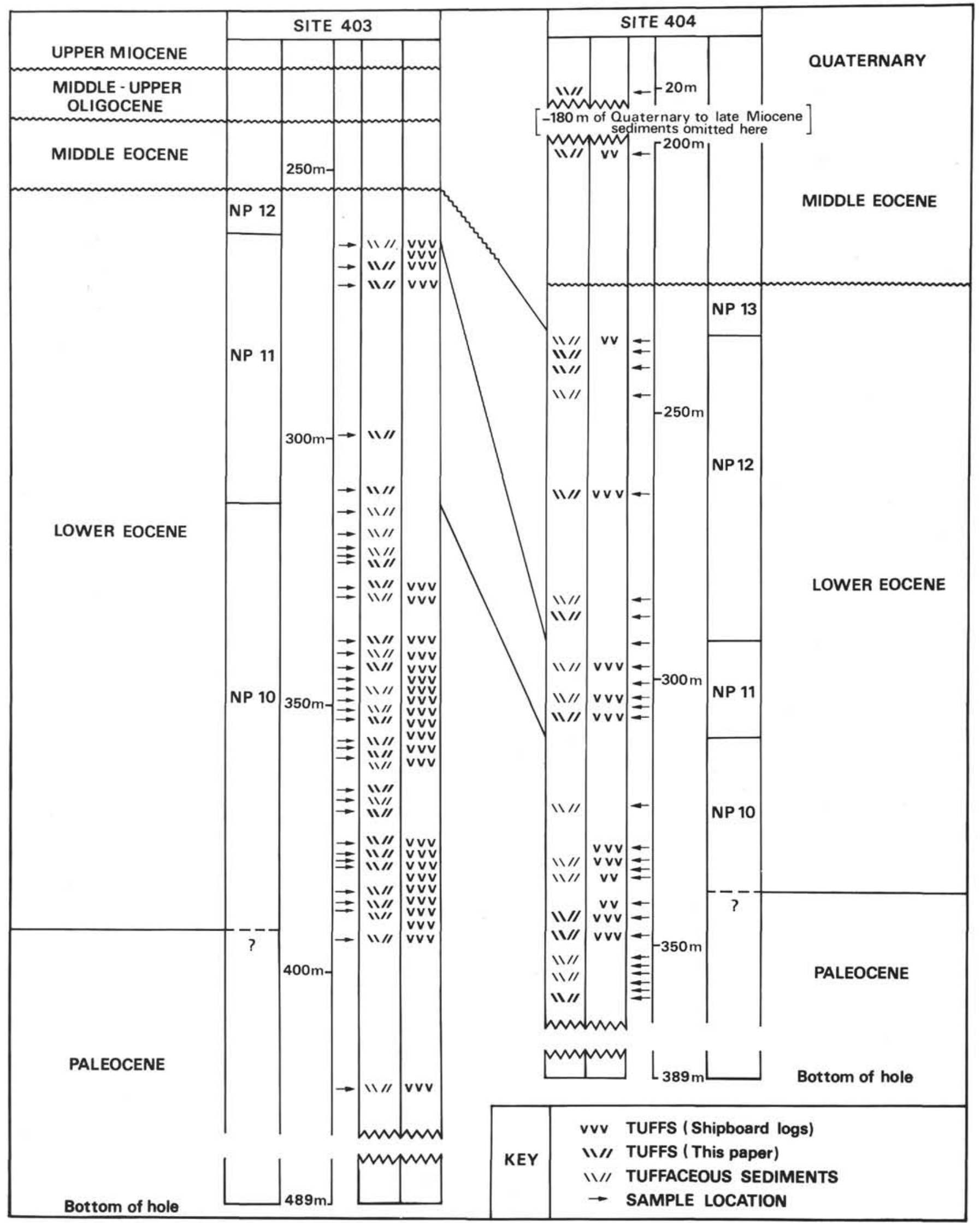

Figure 1. Volcanogenic sediments from Sites 403 and 404; sample depths and stratigraphic relations. 
Nomenclature of the samples is complex since all proportions of volcanogenic, detrital, authigenic, and biogenic materials, and alteration products occur. Due to argillization, proportions of the pyroclasts in particular are difficult to determine. The rocks are named, therefore, on general microscopic appearance, the principal components, and the predominant grain size or other textural feature; modal analyses have not been attempted. The general lithologies and main components are summarized in Figure 2 , column 5, and though much simplified, they illustrate the principal variations between the samples.

\section{Textures, Lithologies}

\section{Site 403, Paleocene and Lower Eocene}

Primary textures of the tuffs (samples containing $>50 \%$ pyroclasts) are largely obscured by argillization of glass, compaction, and diagenetic mineralogic changes. The tuffs are mainly fine grained (granules, sand, and silt); and lapilli $(>4 \mathrm{~mm})$ are rare. In two examples (403-30-1, 34-36 cm; 403-42-3, 64-67 cm), pumice particles attain $1 \mathrm{~cm}$ in length, with vesicles of $0.15 \mathrm{~mm}$ diameter. The average grain size of pyroclasts appears to be about $0.1 \mathrm{~mm}$, but this may be biased since argillized shard particles are obscured in the mud matrix. Within the predominantly sand-grade, or silt-grade tuffs, pyroclasts are moderately well sorted, generally angular, unabraded and are of primary airfall origin (Samples 403-29-5, 83-85 cm; 403-37-1, 47-50 cm; 403-37-2, $121-125 \mathrm{~cm}$; 403-40-1, 46-48 cm; 403-40-2, 98-101 cm; 403-42-2, 91-93 cm; 403-43-1, 5-7 cm). Lapilli are sparse. The only tuff (Sample 404-18-2, 50-52 cm) from Site 404 contains reworked pyroclasts with subordinate epiclasts. Interstitial matrices are mainly of argillized shards from which detrital clay is difficult to distinguish. Some samples (403-35-4, 51-53 cm; 403-40-1, 46-48 cm; 403-41-2, $142-150 \mathrm{~cm} ; 403-42-2,91-93 \mathrm{~cm})$ show pronounced vitroclastic texture (Plate 1, Figure 5). The samples vary from well lithified to unconsolidated mud and silt. In general, the coarser tuffs are more highly lithified because of their closely packed angular constituents and interstitial clay matrix. The tuffaceous mudstones and argillaceous siltstones are more lithified than the slightly or non-tuffaceous muds. The sand-grade tuffs are characterized by fine mottling, an olive-gray (near 5Y 4/1) to olive-black (5Y 2/1) color when dry, with green specks partly due to glauconite. The slightly and non-tuffaceous mudstones and muds of the Site 403 samples are olive-gray, olive-black, gray, gray-black, or brown-black, and are blocky to laminated depending on the proportions and orientation of micas present. Fine primary, dark laminae average $0.2 \mathrm{~mm}$ thick and are prominent in Samples 403-34-5, 36-38 cm; 403-40-2, 98-101 cm; and $403-46-1,28-30 \mathrm{~cm}$. Pyroclastic and orthoclastic silt rarely shows graded bedding (Sample 403-34-5, 36-38 cm), but primary sedimentary structures in the tuffaceous samples are generally obscured by argillization. In several samples (403-37-2, 121-125 cm; 403-36-1, 37-40 cm; 403-37-5, $141-143 \mathrm{~cm} ; 403-38-3,91-93 \mathrm{~cm}$ ), tabular burrows, up to 8 $\mathrm{mm}$ diameter, are filled with micropellets of mudstone. The overall textures of the coarser tuffs and tuffaceous siltstones are greatly modified by complex processes of argillization, glauconitization, and zeolitization, but may indicate a low-energy depositional environment. Several samples (403-29-3, 29-32 cm; 403-40-2, 98-101 cm; 403-41-1, $111-114 \mathrm{~cm}$ ) contain glauconitic ooliths or pseudo-ooliths (commonly with nuclei of pyroclasts) and these may, perhaps, indicate stronger current action during deposition.

\section{Site 404, Lower Eocene}

Tuffs and tuffaceous rocks are much less prominent in the cores from Site 404 than from Site 403, with only one tuff (Sample 404-18-2, 50-52 cm) that is blue-gray and resembles Samples 403-30-1, 34-36 cm; and 403-35-4, 51-53 cm. The tuffaceous samples from Site 404 vary considerably from dusky yellow-green, 5GY5/2 (Sample 404-12-1, 43-47 cm), to olive-black, 5Y2/1 (Sample 404-21-3, 120-122 cm). The most lithified sample $(404-22-3,66-70 \mathrm{~cm})$ contains lapilli (up to $1 \mathrm{~cm}$ long) in a dark gray argillaceous matrix. The other tuffaceous samples examined from Site 404 are argillaceous siltstones with sporadic ooliths and clayey silts. The slightly to non-tuffaceous samples are argillaceous siltstones, clayey silts, silty mudstones and silty muds, with clayey sandstone and biocalcarenite. The finer lithologies are mainly olive-gray (5Y 4/1) to green-gray or dark green-gray (5GY 4/1); the calcarenite (Sample 404-14-1, $42-45 \mathrm{~cm}$ ) is light gray (N7); and a spicular glauconitic sandstone (Sample $404-12-1,43-47 \mathrm{~cm}$ ) is green-gray (5G 6/1).

The single sample of vitroclastic silty clay of Quaternary age $(404-2-6,79-81 \mathrm{~cm})$ is very friable and near light olive-gray (5Y 6/1).

\section{Major Components of the Paleocene and Eocene Samples (Sites 403 and 404)}

The proportions of each component (Figure 2) were estimated visually on thin sections or smear slides of unconsolidated rocks. These components are grouped as pyroclasts, other resistates (probably mainly epiclastic), authigenic minerals, and biogenic materials. Clay-grade matrices include argillized pyroclasts intricately mixed with clastic, neoformed, and diagenetic clay minerals. Pyroclasts are highly variable in type and proportion. The tuff samples contain variable proportions of pumice, shards, microlitic lava, streaky argillized glass, and crystal particles. Crystal particles (unless associated with lava, glass, or pumice) are described as "other resistates" since there is no evidence that they originated as phenocrysts in lava.

Pumice, the most definite pyroclast, is a very variable and major constituent in many tuffs. Lapilli of pumice occur sporadically up to $1 \mathrm{~cm}$ across (Sample 403-42-3, 64-67 cm), but particles are mainly of sand-and-silt-grade and are unabraded. Vesicles range from spheroidal to attenuated in particles even within the same sample (e.g., 403-37-1, 47-50 $\mathrm{cm}$ ) indicating that vesicle shape was determined prior to sedimentation (Plate 1, Figure 1). Vesicles average $0.15 \mathrm{~mm}$ mean diameter in lapilli, and $0.06 \mathrm{~mm}$ in the sand-grade particles. Vesicles are variably filled with spherulitic microcrystalline chlorite, devitrified glass, opaque ore, carbonate, microlitic feldspars, perthite needles, chalcedony, and zeolites, the latter being prominent in Samples 403-42-3, 64-67 cm; and 403-43-1, 5-7 cm. Chlorite commonly lines vesicles (e.g., Sample 403-37-1, $47-50 \mathrm{~cm}$ ). The green to brown glassy base is argillized to chlorite and smectite. Pumice particles may be surrounded by 


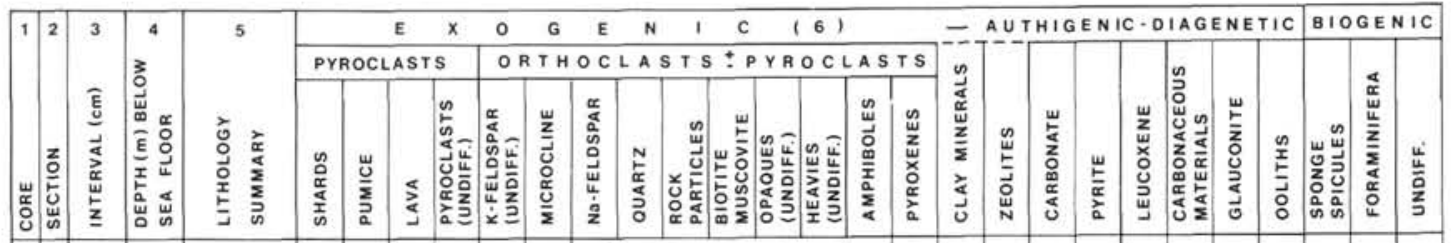

293 29-32 264.3060 .940

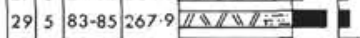

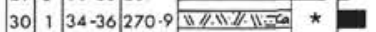

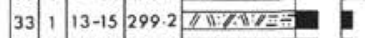

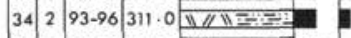

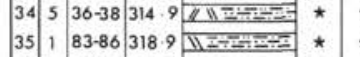

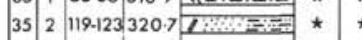

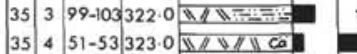

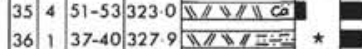

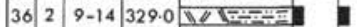

37 1 $47-50337.5$ M $1 / 4 \mathbb{1 . 9}$ *

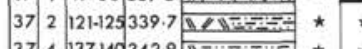

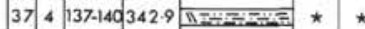

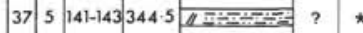

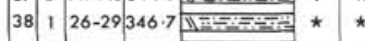

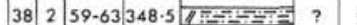

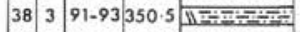

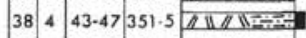

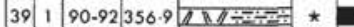

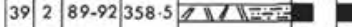

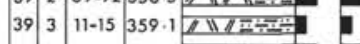

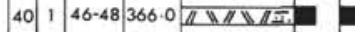

402 98-101 368.0 20.000

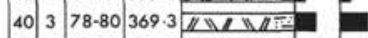

41 1 $111-114376.1 \%$

412 142-150 $378.07 / / \mathbb{N}$ 폴

41 3 147-150379.5 5

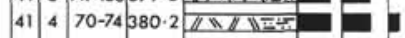

42 1 $56-58385.0 \pi / / 4=$

422 19-93 387.0 1/4

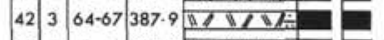

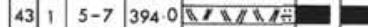

46 1 $28-30$ 422-8 $M$ M

$\begin{array}{ccc} & & \\ \star & \star & \\ \star & \star & \\ & \star & \\ \star & \star & \\ \star & \star & \\ \star & \star & \\ \star & \star & \\ \star & \star & \\ \star & \star & \end{array}$

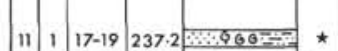

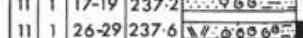

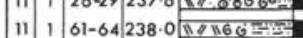

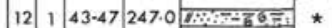

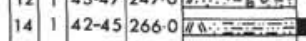

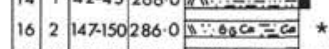

16 3 $15-17$ 287.5 10 10.

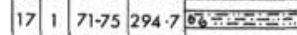

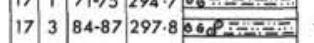

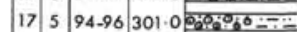

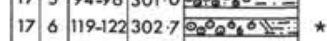

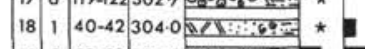

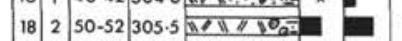

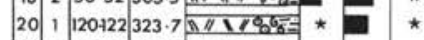

21 1 63.66332 .700

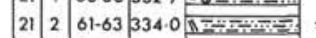

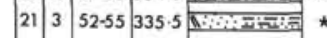

21 4 $56-59337.0$.

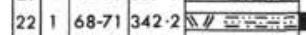

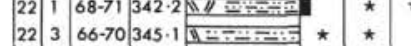

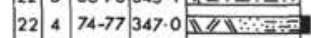

23 1 88.91352 .0 11

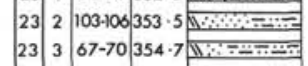

23 4 $486-89356.0$.

$\begin{array}{llllll}23 & 5 & 85-88 & 357.5 & \ldots\end{array}$

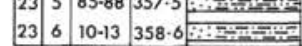

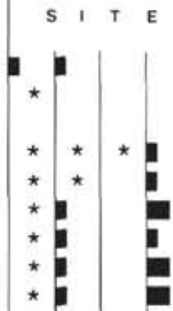

$\begin{array}{llll}\text { E } & 4 & 0 & 3\end{array}$

(I)

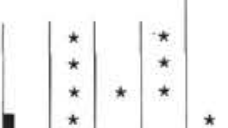

$\begin{array}{lll}* & & \\ * & * \\ * & * \\ * & * \\ * & *\end{array}$

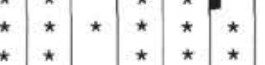

$\star \star \star *$

$\star \star *$

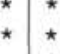

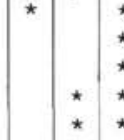

* $\stackrel{\star}{*}$
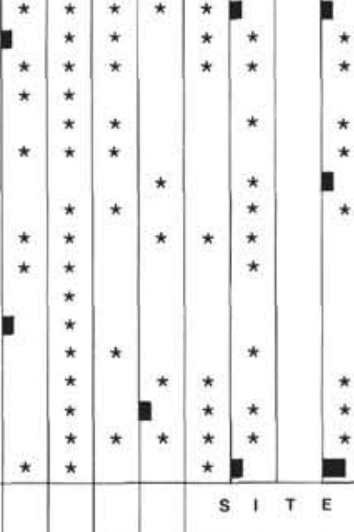

\begin{tabular}{ccccc}
\hline & $\star$ & $\star$ & $\star$ & $\star$ \\
\hline E & 4 & 0 & 4
\end{tabular}

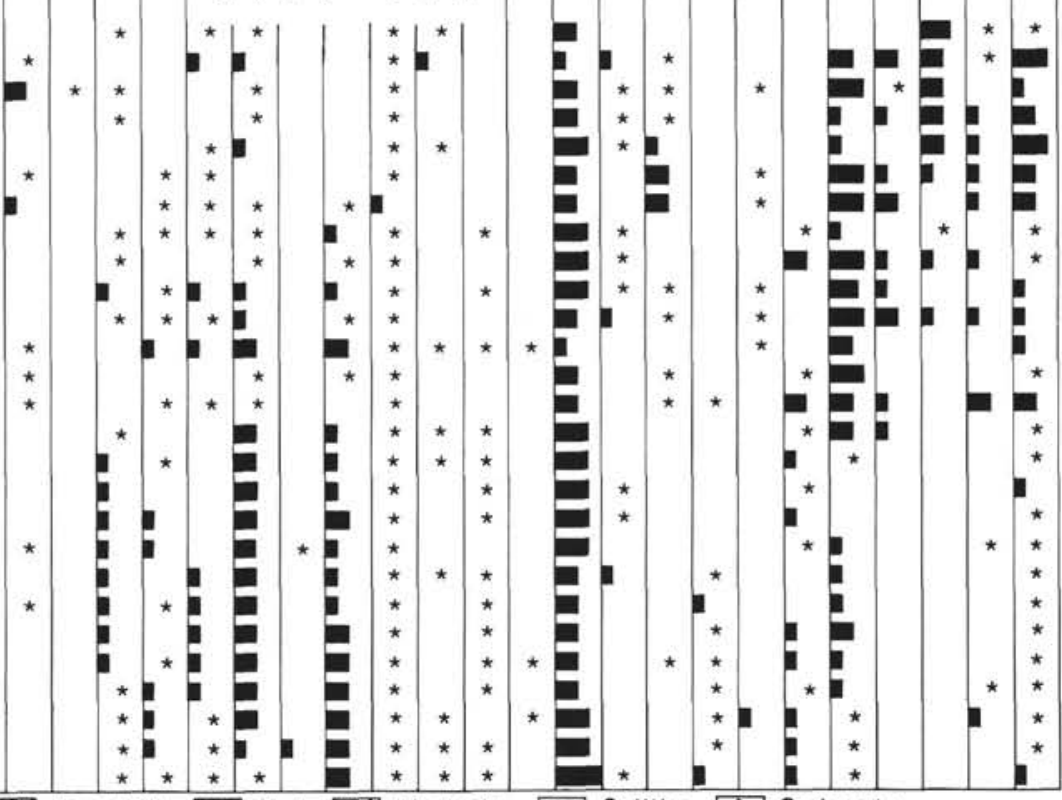

Dominant

66.60 Bioclasts 000 Ooliths Ca Carbonate

Figure 2. Petrographic and mineralogic properties of lower Eocene volcanogenic sediments, Sites 403 and 404, Leg 48. 
a halo of leucoxenic dust. Argillization of pumice was probably controlled by the degree and type of devitrification before deposition. The range of vesicle fillings and alteration of the glassy matrix may also reflect variation in the chemical composition of the parental lava.

Glass shards are abundant in the matrices of the coarser tuffs. In the mudstone samples, shards and vitroclastic texture are difficult to distinguish because of extensive argillization, but less-altered shards rarely occur, e.g., in Sample 403-29-3, 29-32 cm. X-ray diffractometry of altered glass shows it to be mainly smectite and chlorite (e.g., Sample 403-40-1, 46-48 cm). Since both silica-rich (e.g., rhyolites) and silica-poor (e.g., basalt) glasses can alter to smectite, these clay alteration products are not unequivocal indicators of parental lava types. Relatively unaltered shards in one sample (404-18-1, 40-42 cm), however, gave a refractive index of 1.550 , indicating a basaltic affinity.

Particles of lava occur in many of the tuffs, e.g., Sample 403-29-3, 29-32 cm, which contains abundant ooliths of glauconite with nuclei of feldspar-microporphyritic lava (Plate 1, Figures 2,3). Fresh andesine microphenocrysts are set in a devitrified chlorite groundmass. More basic plagioclase needles (up to $0.2 \times 0.03 \mathrm{~mm}$ ) rarely occur in basalt particles with a chloritized groundmass (Sample 403-38-4, 43-47 cm).

The microlitic feldspars are mainly altered and unidentifiable, though commonly chloritized groundmass suggests an intermediate to basic composition (andesite-basalt) of the parental lavas. Unresolved pyroclastic material commonly includes chloritic and smectitized streaks of uncertain affinity.

Feldspars, quartz, and micas occur in variable proportions in most samples, in antipathetic relation to pumice, shards, and microlitic lava (Figure 2). The feldspars range from $\mathrm{K}$-feldspar (orthoclase, microcline) through micro- and crypto-perthite, to plagioclase (albite-oligoclase to labradorite). Feldspars are mainly of sand to fine silt size; there is no relation between the proportion of pyroclasts and abundance or type of feldspar in any one sample. Microlitic lava particles sporadically contain microphenocrysts of plagioclase (Plate 1, Figure 3), which might, however, account for some of the discrete feldspar particles. The tuffs (e.g., Samples 403-29-5, 83-85 cm; 403-33-1, 13-15 cm; 403-41-2, 142 $150 \mathrm{~cm} ; 403-43-1,5-7 \mathrm{~cm}$ ) contain conspicuous particles of oligoclase-andesine and andesine-labradorite (up to $\mathrm{An}_{57}$ ) and these may be pyroclasts, but it is less certain if similar feldspar grains in the slightly or non-tuffaceous samples are of similar origin. Potash feldspar, especially microcline, is ubiquitous and is mainly detrital. In some tuffs (e.g., Sample 403-43-1, 5-7 cm), microcline, microperthite, and oligoclase-andesine are conspicuous (up to $0.3 \mathrm{~mm}$ length); where magmatically corroded, they may be pyroclastic (e.g., Sample 403-37-1, 47-50 cm). Quartz is mainly monogranular, clear, very angular to splintery and of igneous origin, though minor polygranular metamorphic quartz also occurs. Micas comprise glauconite, biotite, muscovite, and illite. Biotite is commonly little altered and occurs mainly with muscovite and chlorite, irrespective of pyroclast content. Clay minerals form the matrices of tuffs and non-tuffaceous rocks. X-ray diffraction analyses indicate that smectite is the major alteration product of pumice, shards, and microlitic lava. Smectite with illite and chlorite also dominate appa- rently slightly tuffaceous silty mudstones (Samples 403-37$4,137-140 \mathrm{~cm} ; 403-37-5,141-143 \mathrm{~cm}$ ), and the smectite has probably been derived from argillized pyroclasts. If so, then these samples were originally more tuffaceous than is apparent from the sections. In an X-ray study of the smectites, $\mathrm{R}$. J. Merriman reports as follows. Inspection of glycerolexpanded (001) reflections at $17 \AA ̊$ showed the smectite to be a well-crystallized variety in all the samples examined (Table 1). These well-crystallized smectites are Class A with positive V/p ratios of between 0.5 and 0.7 (cf. Biscaye, 1965). Smectites of both the dioctahedral and trioctahedral series appear to be present in the core samples. Measurement of the (060) reflection of smectite from Sample 404-14-1, 42-45 cm (film X7743) ${ }^{1}$ indicates that it belongs to the dioctahedral series. On a powder film (X7742) of the clay fraction from Sample $403-40-1,46-48 \mathrm{~cm}$, the same reflection is represented by two lines at $1.50 \AA$ and $1.52 \AA$ (strongest), which suggests that both dioctahedral and trioctahedral types are present, the latter being dominant.

Most samples contain syngenetic glauconite and zeolites. Glauconite forms ooliths, pseudo-ooliths, irregular pellets, and micaceous flakes (in association with other micas). Glauconitic "oolitic" rocks (e.g., Samples 403-29-3, 29-32 $\mathrm{cm}$; 403-40-2, 98-101 cm; 403-40-3, 78-80 cm; 404-11-1, 17-19 cm; 404-11-1, 26-29 cm; 404-16-3, 15-17 cm; 404-18-2, 50-52 cm; 404-22-4, 74-77 cm) show a wide range of oolith and pseudo-oolith structures. The former are prominent in Sample 403-29-3, 29-32 cm (Plate 1, Figure 3), as mainly spheroidal blue-green to yellow-green, concentrically zoned shells averaging 0.3 but reaching $1 \mathrm{~mm}$ mean diameter. The concentric shells average about $7 \mu \mathrm{m}$ thickness and show radial extinction. Many ooliths and unzoned (pseudo-oolith) structures contain nuclei, marginally replaced by glauconite, of pyroclasts feldspar-microlitic lava and feldspars (Plate 1, Figures 2-4). $\mathrm{X}$-ray diffraction photographs of ooliths and pellets from

TABLE 1

X-ray Diffraction Data ${ }^{\mathrm{a}}$ of Selected Samples ${ }^{\mathrm{b}}$ From the Volcanogenic Series, Sites 403 and 404

\begin{tabular}{|c|c|c|}
\hline Core Sample & Clay Minerals & Other Minerals Detected \\
\hline $\begin{array}{l}\text { 403-29-5, 83-85 cm } \\
\text { Tuff }\end{array}$ & Smectite, illite, chlorite & $\begin{array}{l}\text { Quartz (1\%), feldspar (mainly plagioclase), } \\
\text { clinoptilolite (trace), zeolite, green cavity } \\
\text { lining is mostly celadonite (film X7626) }\end{array}$ \\
\hline $\begin{array}{l}403-37 \cdot 1,47-50 \mathrm{~cm} \\
\text { Tuff }\end{array}$ & Smectite, illite, chlorite & Quartz, plagioclase + K-feldspar, mica \\
\hline $\begin{array}{l}403-37-4,137-40 \mathrm{~cm} \\
\text { Slightly tuffaceous } \\
\text { mudstone }\end{array}$ & Illite, smectite, chlorite & $\begin{array}{l}\text { Quartz, plagioclase + K-feldspar, mica, } \\
\text { clinoptilolite, amphibole, pyrite, gypsum, } \\
\text { ?analcime (trace) }\end{array}$ \\
\hline $\begin{array}{l}403-37-5,141-143 \mathrm{~cm} \\
\text { Slightly tuffaceous } \\
\text { mudstone }\end{array}$ & Smectite, chlorite & $\begin{array}{l}\text { Quartz, calcite, plagioclase + K-feldspat, } \\
\text { mica, clinoptilolite, gypsum, amphibole, } \\
\text { pyrite }\end{array}$ \\
\hline $\begin{array}{l}\text { 403-39-1, } 90-92 \mathrm{~cm} \\
\text { Tuffaceous } \\
\text { mudstone }\end{array}$ & Smectite, illite & $\begin{array}{l}\text { Quartz, calcite, plagioclase, clinoptilolite, } \\
\text { pyrite }\end{array}$ \\
\hline $\begin{array}{l}403-40-1,46-48 \mathrm{~cm} \\
\text { Tuff }\end{array}$ & Smectite, chlorite (trace) & Quartz (1\%), plagioclase \\
\hline $\begin{array}{l}\text { 403-40-2, } 98-101 \mathrm{~cm} \\
\text { Glauconitic tuff- } \\
\text { aceous mudstone }\end{array}$ & Smectite, illite, chlorite & $\begin{array}{l}\text { Quartz, calcite, plagioclase, clinoptilolite, } \\
\text { pyrite, gypsum, amphibole }\end{array}$ \\
\hline $\begin{array}{l}404-2-6,79-81 \mathrm{~cm} \\
\text { Vitroclastic ooze }\end{array}$ & Illite, chlorite & $\begin{array}{l}\text { Quartz, calcite, plagioclase }+K \text {-feldspar, } \\
\text { halite }\end{array}$ \\
\hline $\begin{array}{l}404-14-1,42-45 \mathrm{~cm} \\
\text { Tuffaceous mud- } \\
\text { stone }\end{array}$ & Smectite & Calcite, plagioclase, halite \\
\hline
\end{tabular}

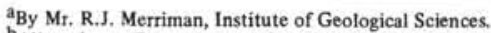

${ }^{b}$ All are lower Eocene except Sample 404-2-6, 79-81 cm, which is Quaternary.

${ }^{1} \mathrm{X}$ numbers refer to the XRD library of the Institute of Geological Sciences, London. 
Samples 403-30-1, 34-36 cm (X7597); 404-11-1, 17-19 cm (X7690); and 404-17-5, 94-96 cm (X7689) show predominant glauconite of Class 2 (Bentor and Kastner, 1965) with significant expansible layers. The possibility remains that glauconite may have completely replaced primary chamositic ooliths. Glauconite-ooliths and structureless pellets occur together (e.g., in Sample 403-40-2, 98-101 cm) in laminae which disrupt the bedding. Irregular and microenterolithic patches of glauconite (e.g., Sample 404-11-1, 26-29 cm) may accompany ooliths and replace or penetrate other constituents such as radiolarians and central axes of sponge spicules. Glauconite (as well as zeolite) is unrelated to the pyroclast content, and occurs in tuffs and non-tuffaceous samples. Glauconite forming discrete flakes (pleochroism $\mathrm{X}=$ yellow-green; $\mathrm{Z}=$ green) is probably detrital, whereas the oolitic and pellety variety is authigenic. Zeolites occur mainly in pores in the clay matrices of the tuffs and other sediments and also in vesicles (with chlorite and silica) of pumice particles (e.g., Samples 403-38-4, 43-47 cm; 403-41-3, 147-150 cm; 403-42-3, 64-67 cm). Microlitic lava particles and shards are also sporadically zeolitized (Sample 403-40-2, 98-101 cm). $\mathrm{X}$-ray diffraction data (Table 1) show clinoptilolite to be the dominant zeolite (e.g., in Sample 403-37-5, 141-143 cm), with minor analcime. Of the other non-detrital minerals (which include pyrite, leucoxene, carbonate, and opaque oxides), calcite cement marginally replaces clinoptilolite in one sample (404-11-1, 17-19 cm).

Bioclasts occur in many samples including volcanogenic sediments. In the higher samples from Site 404, bioclasts are common and include sponge spicules, foraminifers, radiolarians, and particles of collophane. Pyroclastic spicular clayey silts (Samples 404-8-2, 24-26 cm; 404-11-1, 17-19 $\mathrm{cm})$ are composed largely of chalcedonic sponge spicules which in one sample $(404-11-1,26-29 \mathrm{~cm})$, together with foraminifers and radiolarians, are of well-sorted sand-grade. An argillaceous siltstone (Sample 404-14-1, 43-45 cm) is similarly composed of well-sorted spicules, radiolarians, and foraminifers with a silty and clayey matrix containing shards. Cellular carbonaceous particles occur in the darker mudstones (e.g., Sample 404-22-1, 68-71 cm), and particles of bivalves and echinoderm plates also occur sparsely.

\section{Minor Components: Heavy Minerals}

Heavy mineral suites from 21 of the volcanogenic and other samples of Site 403, and 17 samples from Site 404 are detailed below by one of the authors (ACM). Heavy minerals (especially amphiboles and pyroxenes) are relatively conspicuous in thin sections as discrete angular grains of silt-to-fine sand-grade and as more rounded coarser grains. They occur in both tuffaceous and non-tuffaceous samples.

The samples were disaggregated by ultrasonic vibrator, with brief immersion in dilute hydrochloric acid for carbonate-cemented rocks. Heavy minerals were separated using bromoform (sp. gr. 2.8) stabilized with ethanol: the resulting separates were mounted, examined optically and a minimum of 200 grains counted. The following minerals were identified; their distribution in samples from Sites 403 and 404 are shown in Tables 2 and 3, respectively.

Allanite

Brown to dark brown pleochroism, subrounded grains
Anatase

Apatite

Augite

Biotite

Chlorite

Chloritoid

Clinozoisite

Diopside

Epidote

Garnet

Hornblende

Hypersthene

Kyanite

Muscovite

Olivine

Piedmontite

Rutile

Sillimanite

Sphene

Spinel

Staurolite

Tourmaline

Tremolite

Zircon
Pale yellow-brown, euhedral to subrounded rectangular plates; probably authigenic, hence not included in the count

Colorless to pale pink, slightly pleochroic, subrounded prismatic or fractured grains

Colorless, slightly rounded fractured prisms, grading to well-rounded egg-shaped grains

Pale brown to brown; strongly colored grains show weak pleochroism; angular to subrounded, rarely euhedral commonly enclosing, or attached to, plagioclase laths; slightly etched

Variable from yellow-brown, through brown, to green-brown, cleavage flakes. Not included in the count due to its tendency to float in bromoform, causing incomplete separation

Green-blue, cleavage flakes; not included in the count

Slate-blue, fractured platy grains

Colorless, mainly subrounded; rare fractured euhedra occur

Pale green to green, subrounded grains, commonly intensely etched

Yellow-green, moderate to strong pleochroism, mainly subrounded; rare fractured euhedra; commonly slightly altered

Colorless to pink, rounded, euhedral to anhedral grains; sporadic etch-pits

Variable from green-brown, through pale green, green, brown-green, to blue-green; grains fractured, angular to subrounded; commonly intergrown with epidote

Moderate to strong pink to green pleochroism; generally fractured, subrounded; slightly etched

Colorless, fractured grains, angular to subrounded

Colorless or very pale green, cleavage flakes not included in the count

Lemon-yellow; subrounded

Characteristic orange to mauve pleochroism, subrounded, commonly intergrown with epidote

Yellow-brown, subrounded grains

Colorless, angular fractured

Colorless, euhedral to subrounded

Blue-green (probably pleonaste), subrounded

Golden yellow, moderately pleochroic; rounded grains

Yellow, brown and, less commonly, pink varieties; generally subrounded fractured prisms

Colorless, angular to subrounded grains

Two varieties, purple and colorless, in equal proportions throughout; grains grade from perfectly euhedral to rounded 
TABLE 2

Results of Heavy Mineral Analyses on Samples From DSDP Leg 48 Site 403

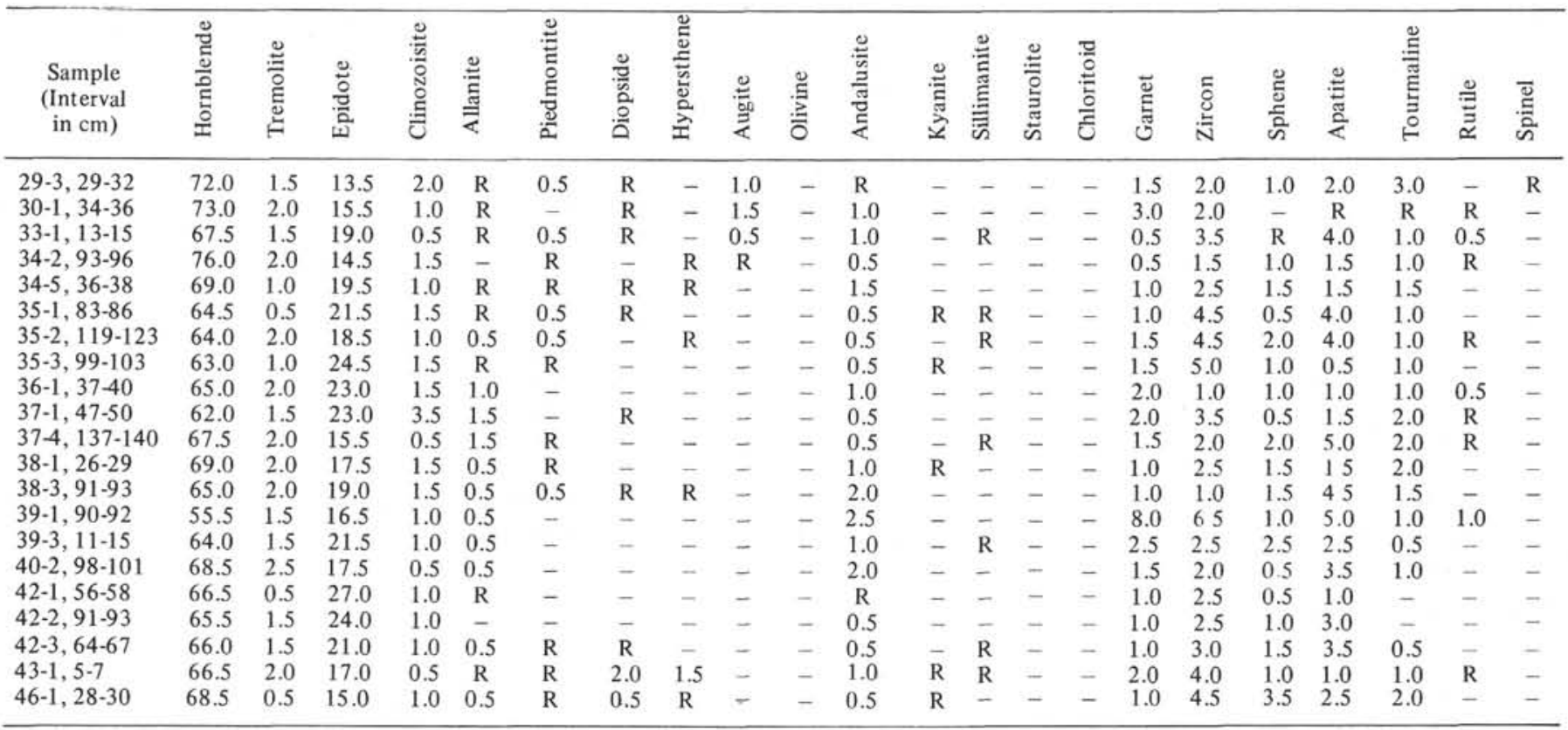

Note: Proportions of heavy minerals are indicated by percentages unless less than $0.5 \%$ which are indicated as rare (R). Also present: biotite (common), muscovite, chlorite, and anatase (rare).

TABLE 3

Results of Heavy Mineral Studies on Samples From DSDP Leg 48, Site 404

\begin{tabular}{|c|c|c|c|c|c|c|c|c|c|c|c|c|c|c|c|c|c|c|c|c|c|c|}
\hline $\begin{array}{c}\text { Sample } \\
\text { (Interval in } \mathrm{cm} \text { ) }\end{array}$ & 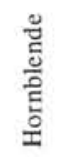 & $\begin{array}{l}\stackrel{\Xi}{0} \\
\stackrel{\Xi}{\Xi} \\
\text { હ }\end{array}$ & 产 & 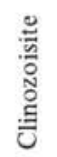 & 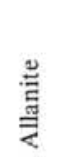 & 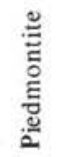 & $\begin{array}{l}\frac{\mathscr{0}}{\omega} \\
\stackrel{0}{0} \\
\stackrel{0}{0}\end{array}$ & 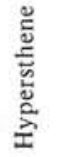 & 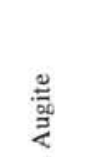 & 胥 & 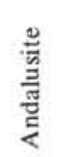 & 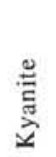 & $\begin{array}{l}\text { 气 } \\
\text { 总 } \\
\text { 营 }\end{array}$ & 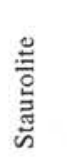 & 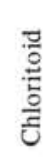 & હ & $\begin{array}{l}\text { ¿ } \\
\text { 离 }\end{array}$ & $\frac{\text { ̆ }}{\frac{\Xi}{2}}$ & 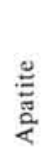 & 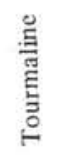 & 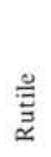 & $\begin{array}{l}\bar{\Xi} \\
\text { के }\end{array}$ \\
\hline $2-6,79-81$ & 30.5 & 0.5 & 2.5 & - & - & - & - & - & 63.0 & - & $\mathrm{R}$ & - & - & - & - & 0.5 & 0.5 & - & 3.0 & - & - & - \\
\hline $8-2,24-26$ & $\mathrm{R}$ & - & - & - & - & - & - & - & 99.0 & 1.0 & - & - & - & - & - & - & - & - & - & - & - & 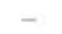 \\
\hline $11-1,26-29$ & - & - & - & - & - & - & - & - & 100.0 & - & - & - & - & - & - & - & - & - & - & - & - & - \\
\hline $12-1,43-47$ & $\mathrm{R}$ & - & - & - & - & - & - & - & 100.0 & - & - & - & - & - & - & - & - & - & - & - & - & - \\
\hline $16-3,15-17$ & 3.0 & - & 1.0 & - & - & - & 78.0 & 12.5 & - & - & - & - & - & - & - & 1.0 & 1.0 & - & 2.5 & 1.0 & - & - \\
\hline $17-3,84-87$ & 45.5 & 1.0 & 7.5 & 2.0 & - & - & 1.0 & 6.0 & 25.0 & - & $\mathrm{R}$ & - & - & - & - & 1.5 & 4.5 & $\mathrm{R}$ & 5.0 & 1.0 & - & - \\
\hline $17-5,94-96$ & 66.5 & 2.0 & 8.0 & 0 & - & $\mathrm{R}$ & 0.5 & $\mathrm{R}$ & 2.5 & - & $\mathrm{R}$ & - & - & - & _- & 2.5 & 6.0 & 2.0 & 1.0 & 7.5 & $\mathrm{R}$ & - \\
\hline $18-2,50-52$ & 75.0 & 2.5 & 14.0 & 1.0 & 0.5 & - & - & $\mathrm{R}$ & $\mathrm{R}$ & - & 0.5 & - & - & - & - & 1.0 & 1.0 & 1.5 & 2.5 & 1.0 & - & - \\
\hline $20-1,120-122$ & 71.0 & 0.5 & 18.0 & 1 & 1.0 & $\mathrm{R}$ & 0.5 & 0.5 & R & - & 0.5 & - & - & - & - & 2.0 & 1.0 & - & 2.0 & 1.0 & - & ... \\
\hline $21-2,61-63$ & 76.0 & 1.5 & 10.5 & 1.0 & 0.5 & 0.5 & 0.5 & $\mathrm{R}$ & - & - & 0.5 & - & - & 0.5 & - & 1.5 & 3.0 & 0.5 & 2.5 & 1.0 & - & \\
\hline $21-4,56-59$ & 67.0 & 2.0 & 17.5 & 3.5 & $\mathrm{R}$ & - & - & - & - & - & 0.5 & $\mathrm{R}$ & $\mathrm{R}$ & - & - & 1.5 & 3.0 & 0.5 & 2.0 & 0.5 & - & - \\
\hline $22-3,66-70$ & 69.5 & 2.0 & 15.0 & 1.0 & 0.5 & _- & - & $\mathrm{R}$ & _- & - & 1.0 & - & $\mathrm{R}$ & - & - & 1.5 & 4.5 & 1.0 & 3.0 & 1.0 & $\mathrm{R}$ & - \\
\hline $23-1,88-91$ & 68.5 & 3.0 & 17.0 & 1.5 & 1.0 & - & - & - & - & - & 1.0 & - & - & - & - & 2.5 & 1.5 & 0.5 & 2,0 & 1.5 & $\mathrm{R}$ & - \\
\hline $23-3,67-70$ & 71.5 & 1.0 & 14.0 & 3.5 & 0.5 & $\mathrm{R}$ & - & - & - & - & 0.5 & - & - & - & - & 1.5 & 1.5 & 2.0 & 3.0 & 1.0 & $\mathrm{R}$ & - \\
\hline $23-4,86-89$ & 65.0 & 1.0 & 25.0 & 2 & 0 . & $\mathrm{R}$ & - & - & - & - & 0.5 & - & $\mathrm{R}$ & - & - & 1.5 & 2.0 & 0.5 & 1.0 & 0.5 & - & \\
\hline $23-5,85-88$ & 70.0 & 1.5 & 18.0 & 2.5 & 0.5 & - & - & - & - & - & 1.0 & - & - & - & - & 2.0 & 2.0 & 1.0 & 1.0 & 0.5 & $\mathrm{R}$ & - \\
\hline $23-6,10-13$ & 66.0 & 1.0 & 18.5 & 3.5 & 0.5 & $\mathrm{R}$ & $\mathrm{R}$ & $\mathrm{R}$ & - & - & 0.5 & - & - & - & - & 2.5 & 4.0 & 0.5 & 2.0 & 1.0 & - & - \\
\hline
\end{tabular}

Note: Proportions of heavy minerals are indicated by percentages unless less than $0.5 \%$, which are indicated as rare (R). Also present, biotite (common in $2-6,79-81 \mathrm{~cm}$, and $16-3,15-17 \mathrm{~cm}$ to $23-6,10-13 \mathrm{~cm}$; rare in $8-2,24-26 \mathrm{~cm}$ ); muscovite, chlorite (only in $2-6,79-81 \mathrm{~cm}$ and $16-3,15-17 \mathrm{~cm}$ to 23-6, 10-13).

Three distinct heavy mineral assemblages occur (Tables 2 and 3). Assemblage 1 is $68.5 \%$ hornblende, $18 \%$ epidote, $3 \%$ zircon, $2.5 \%$ apatite, $1.5 \%$ tremolite, $1.5 \%$ clinozoisite, $1.5 \%$ garnet, $1 \%$ tourmaline, $1 \%$ sphene, $1 \%$ andalusite, and $0.5 \%$ allanite, with rare kyanite, piedmontite, rutile, sillimanite, and spinel; biotite is common and muscovite is present in this assemblage. Assemblage 2 is $81.5 \%$ diopside, $13 \%$ hypersthene, $2.5 \%$ apatite, $1 \%$ garnet, $1 \%$ zircon, and $1 \%$ tourmaline; biotite is present and muscovite is rare. Assemblage 3 is $99.5 \%$ augite and $0.5 \%$ olivine.
Assemblages 1 and 2 undoubtedly were derived from metamorphic basement. Various dredges and drill cores of the metamorphic basement in the Rockall area (Roberts et al., 1972; Roberts et al., 1973) have yielded granulites containing diopside, hypersthene, garnet, etc., of Lewisian affinities; the heavy minerals of Assemblage 2 could well be derived from similar granulites. Discoveries of rocks containing the minerals of Assemblage 1 are less well documented, but Carruthers et al. (1923) report pebbles of amphibolite containing various shades of green hornblende, 
with minor epidote, zoisite, and sphene, as well as gneiss containing tremolite and epidote, from the Lousy Bank; Harding (this volume) notes the presence of similar material (Samples 405-25-1, 6-8 cm; 405-27-1, 9-11 cm).

Factors such as grain-size availability and hydraulic conditions cause minor variations in proportions of minerals in heavy residues (Rittenhouse, 1943). Amphibole proportions correlate well with grain size in the samples from Site 403 (Figure 3) and this correlation is interpreted as a function of amphibole availability. Some variation in hornblende proportions may possibly be due to pyroclastic hornblende, but the good amphibole percentage grain-size correlation and the fact that the hornblende, although variable from brown-green to blue-green, seems to form a single population, suggests that all the hornblende has been derived from a metamorphic source. This also accounts for other mineral species of Assemblage 1.

Assemblage 3 was probably derived from a basaltic source rock on the basis of ophitic texture of the augite and the associated (minor) olivine. Augite proportions do not correlate with pyroclastic grains nor are mutual contacts obvious, suggesting that Assemblage 3 is wholly detrital and not of direct tuff-fall origin. Moreover, the simple and unusual composition of this assemblage suggests closeness of the source-rocks, basalt being widespread over the Rockall Plateau.

The samples from Site 403 are all dominated by Assemblage 1 with minor Assemblage 2 near the base and Assemblage 3 near the top of the succession. Samples from Site 404 show a more complex pattern (Figure 4) the lower 10
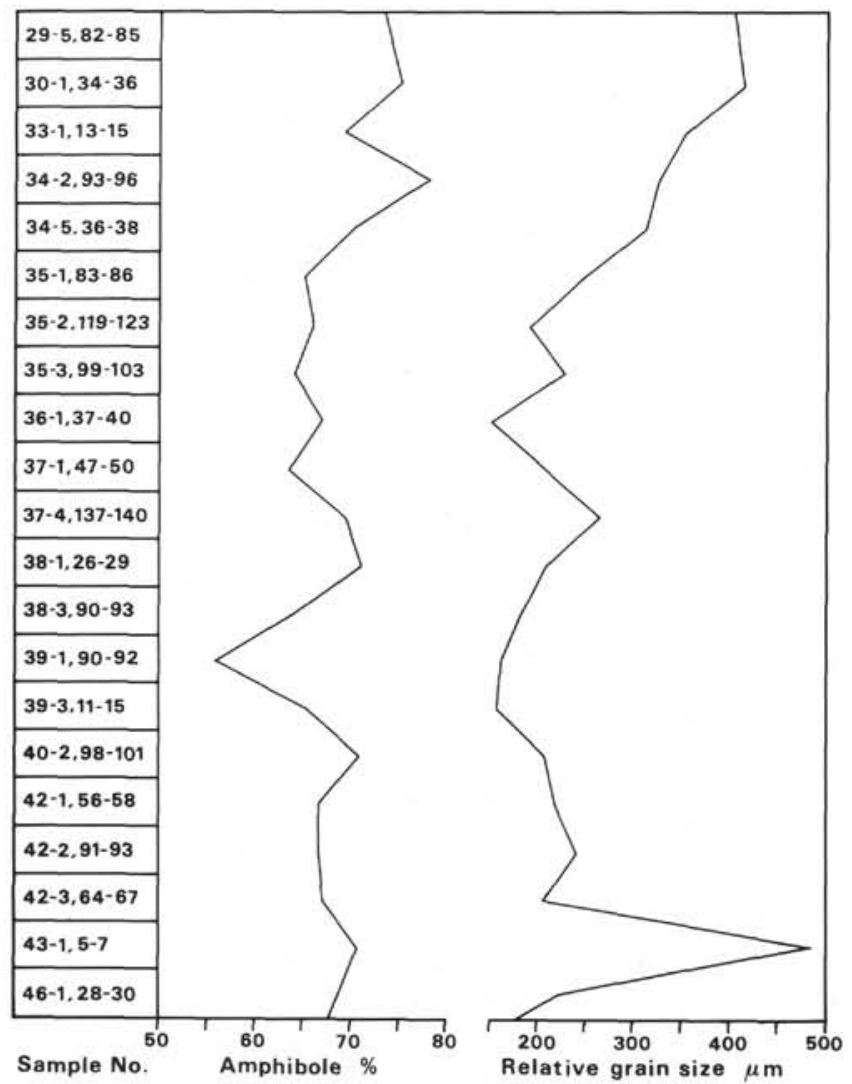

Figure 3. Relationship of grain size to proportion of amphibole in heavy residues from Site 403. samples are dominantly Assemblage 1, whereas Assemblage 3 increases in importance to account entirely for Samples 404-12-1, 43-47 cm; 404-11-1, 26-29 cm; and 404-8-2, $24-26 \mathrm{~cm}$. Assemblage 1 only reappears in Sample 404-2-6, $79-81 \mathrm{~cm}$. This gradual change relates to a gradual change in source rocks. The penecontemporaneous vulcanism may perhaps indicate an incursion of basaltic lava in the source area. The abrupt incursion of Assemblage 2 in Sample 404-16-3, 15-17 cm, which eliminates the otherwise increasing influence of Assemblage 3, indicates a sudden and relatively brief influx of detritus from a different provenance.

The angular, commonly euhedral grains in each assemblage indicate little attrition; their source rocks, therefore, were moderately proximal to the basin of sedimentation. More rounded grains, as in the uppermost samples from Site 403 (where even hornblende grains show some rounding), indicate longer reworking of the sediment, rather than a more distant source area. Diagenetic modification of the heavy minerals has not been appreciable; although diopside is intensely etched, it is rarely skeletal. Augite, hypersthene, and garnet are also etched to a limited extent. Anatase may be authigenic.

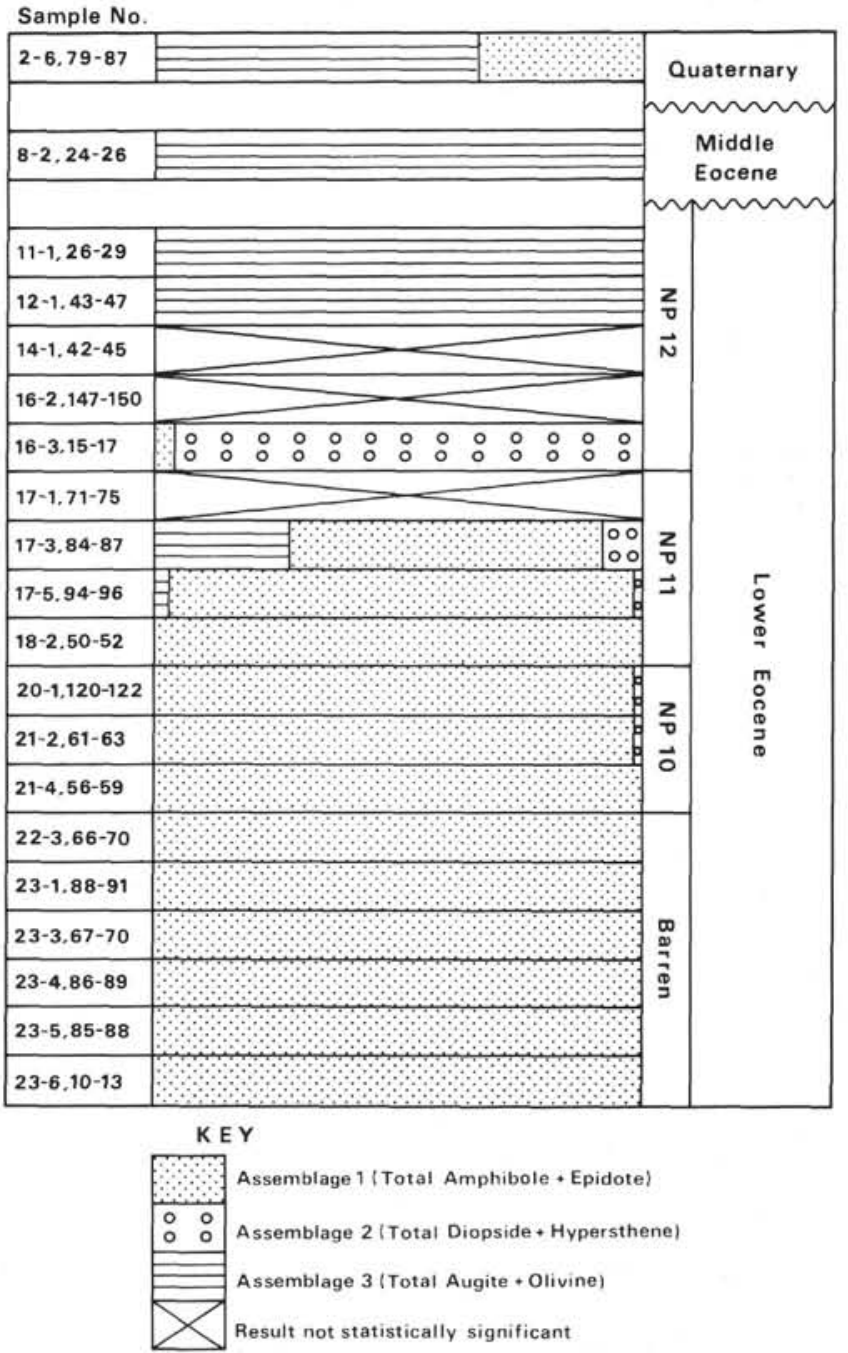

Figure 4. Variations in heavy mineral assemblages from Site 404. 
Thus, three heavy mineral assemblages have been recognized: two derived from metamorphic basement, and the third by denudation of a basaltic source. The pyroclasts are not directly correlated with this third assemblage, and the volcanic contribution to these sediments was both detrital and pyroclastic.

\section{CHEMISTRY}

Partial chemical analyses, by atomic absorption spectroscopy, of two tuffs (one vitroclastic mudstone and one silty mudstone) are listed in Table 4 . Brief petrographical details are as follows: Analysis 1 - This pyroclastic silty mudstone (Sample 403-38-2, 59-62 cm) consists of silt grains of $\mathrm{K}$-feldspar, albite to andesine, biotite, chlorite, hornblende, and apatite in a clay base with carbonaceous and pyritic dust.

Analysis 2 - This sample (403-39-2, 89-92 cm) of vitroclastic mudstone is composed of closely packed, silt-grade, well-sorted argillized shards, with sparse quartz, specks of glauconite, and sparse foraminifers in a dominantly clay base with carbon grains.

Analysis 3 - This sample (403-41-4, 70-74 cm), pumiceous, heterolithic argillized crystal-tuff, is an aggregate of closely packed, well-sorted fine sand- and silt-grade chloritized and zeolitized pumice, microlitic lava, argillized shards, scattered oligoclase-andesine crystals, foraminifers preserved in carbonate, scattered glauconite pellets, and clay matrix.
Analysis 4 - Pumiceous sandy tuff (Sample 403-43-1, $5-7 \mathrm{~cm}$ ) consists mainly of poorly sorted chloritized pumice (up to $4 \mathrm{~mm}$ ), streaky and microlitic lava, with interstitial detrital sand grains of microcline, lesser quartz (single and polygranular), sodic plagioclase, minor biotite, traces of hornblende, much chlorite, minor glauconite, and interstitial clay.

The mineral composition of these samples is complex and the analyses are difficult to interpret. Quartz and feldspars contribute to the relatively high $\mathrm{SiO}_{2}, \mathrm{~K}_{2} \mathrm{O}$ and $\mathrm{Al}_{2} \mathrm{O}_{3}$ in Analysis 4 compared with the other tuff (Analysis 3), whereas the $\mathrm{CaO}$ content of the latter is due to foraminifers. The argillized vitroclastic mudstone (Analysis 2) is the most homogeneous. Comparison of the latter sample with lower Eocene tuffs from Monsted, Denmark (Madirazza and Fregerslev, 1969) shows marked differences especially in higher $\mathrm{Na}_{2} \mathrm{O}, \mathrm{MgO}$, and lower $\mathrm{Fe}_{2} \mathrm{O}_{3}$ and $\mathrm{TiO}_{2}$ in the present samples. Little similarity is evident between the Site 403 sample analyses and Analysis A (Table 4) of chloritized and carbonated olivine-basalt of Paleocene age from IPOD Leg 12. Site 117A, from the Hatton-Rockall Basin (Sabine, 1972). There is considerable variation in trace element contents between the four Site 403 samples reflected in their variable mineralogy, though $\mathrm{Cr}, \mathrm{Co}, \mathrm{Ni}$, and $\mathrm{Zn}$ are of similar orders of magnitude. In comparison with the altered basalt (Analysis A), only Co shows any similarity. In general, the bulk composition of the mudstones (Analyses 1 and 2) approaches that of bentonitic smectite than chlorite on the contents of $\mathrm{SiO}_{2}, \mathrm{Al}_{2} \mathrm{O}_{3}, \mathrm{MgO}$, and $\mathrm{Na}_{2} \mathrm{O}$.

TABLE 4

Partial Chemical Analyses of Volcanogenic Sediments From Site 403

\begin{tabular}{|c|c|c|c|c|c|}
\hline Analysis No. & 1 & 2 & 3 & 4 & $\mathrm{a}$ \\
\hline Sample & $403-38-2,59-63 \mathrm{~cm}$ & $403-39-2,89-92 \mathrm{~cm}$ & $403-41-4,70-74 \mathrm{~cm}$ & $403-43-1,5-7 \mathrm{~cm}$ & $117 \mathrm{~A}-11-2$ \\
\hline Lab..No. & 2814 & 2815 & 2816 & 2817 & 2197 \\
\hline Rock name: & $\begin{array}{c}\text { Pyroclastic } \\
\text { carbonaceous mudstone }\end{array}$ & $\begin{array}{l}\text { Pumiceous } \\
\text { mudstone }\end{array}$ & $\begin{array}{l}\text { Pumiceous } \\
\text { crystal tuff }\end{array}$ & $\begin{array}{l}\text { Heterolithic } \\
\text { tuff }\end{array}$ & $\begin{array}{c}\text { Chloritized } \\
\text { basalt }\end{array}$ \\
\hline \multicolumn{6}{|l|}{ (Per cent) } \\
\hline $\mathrm{SiO}_{2}$ & 54.2 & 50.8 & 47.3 & 52.7 & 43.33 \\
\hline $\mathrm{Al}_{2} \mathrm{O}_{3}$ & 13.1 & 11.4 & 11.4 & 12.8 & 14.73 \\
\hline $\mathrm{Fe}_{2} \mathrm{O}_{3}$ & 4.8 & 9.1 & 10.4 & 9.4 & 4.13 \\
\hline $\mathrm{FeO}$ & 3.1 & 5.2 & 3.7 & 4.3 & 6.54 \\
\hline $\mathrm{MgO}$ & 3.0 & 8.8 & 8.3 & 6.9 & 8.54 \\
\hline $\mathrm{CaO}$ & 3.1 & 2.1 & 3.2 & 1.6 & 9.24 \\
\hline $\mathrm{Na}_{2} \mathrm{O}$ & 3.3 & 3.0 & 4.8 & 3.7 & 2.37 \\
\hline $\mathrm{K}_{2} \mathrm{O}$ & 3.0 & 0.8 & 1.6 & 2.9 & 0.81 \\
\hline $\mathrm{TiO}_{2}$ & 0.93 & 1.88 & 1.26 & 1.14 & 1.88 \\
\hline $\mathrm{MnO}$ & 0.07 & 0.07 & 0.11 & 0.11 & 0.31 \\
\hline Total & 88.60 & 93.15 & 92.07 & 95.45 & 91.88 \\
\hline Rem. & 11.40 & 6.85 & 7.93 & 4.55 & 9.12 \\
\hline \multicolumn{6}{|l|}{$(\mathrm{mg} / \mathrm{kg})$} \\
\hline $\mathrm{Cu}$ & 95 & 130 & 165 & 225 & 66 \\
\hline $\mathrm{Sr}$ & 370 & 130 & 135 & 150 & 530 \\
\hline $\mathrm{Ba}$ & 405 & 75 & 100 & 340 & 190 \\
\hline V & 145 & 365 & 365 & 255 & 120 \\
\hline $\mathrm{Cr}$ & 90 & 55 & 85 & 65 & 390 \\
\hline Co & 50 & 80 & 85 & 60 & 51 \\
\hline $\mathrm{Ni}$ & 85 & 80 & 95 & 95 & 190 \\
\hline $\mathrm{Zn}$ & 130 & 170 & 135 & 115 & n.d. ${ }^{b}$ \\
\hline
\end{tabular}

Note: Analysts (1-4) were J.P. Arnold and S. Jones, Laboratory of the Government Chemist, London, England.

aChloritized basalt, 311-313 m sub-bottom, Site 117A, Leg 12, DSDP, Rockall Plateau (Sabine, 1972).

b.d. not determined. 


\section{DISCUSSION}

The samples examined from Sites 403 and 404 indicate sporadic penecontemporaneous vulcanism in the late Paleocene, the early Eocene (Ypresian), and the middle Eocene (Lutetian), with a final outburst in the Quaternary. The most tuffaceous rocks occur in some 200 meters of the basal Paleocene-Eocene of Site 403 (Figure 2); correlation with Site 404 (Figure 1) shows a more condensed sequence (about $30 \mathrm{~cm}$ ) for Nannoplankton Zone (NP) 10 in Site 404 compared with Site 403. The dominant tuffs and tuffaceous mudstones of NP 10 in Site 403 are not represented in the NP 10 samples of nearby Site 404 . Tuffaceous material may have been destroyed more rapidly through a higher energy environment at Site 404, as indicated by the overall higher resistate content of the samples there. The sedimentological and structural interpretation of this anomaly is discussed elsewhere in this volume, but the rate of subsidence was greater at Site 403 than at Site 404, the latter lying closer than the former to the fault-bounded rifted margin of the southwest Rockall Plateau. Contemporaneous ashfall over Site 404 , therefore, might have been reworked and dispersed, while over Site 403 accumulation of tephra was less disturbed.

The Paleocene-lower Eocene tuffs from Site 403 are mostly fine grained with sparse lapilli; no agglomerates were cored. If comminution during aeolian transport and marine sedimentation were insignificant, the mean particle size (about $0.1 \mathrm{~mm}$ ) would indicate a very distant volcanic source, of at least $100 \mathrm{~km}$, by analogy with ashfall from the Vesuvian eruption of 79 AD (Francis, 1976). However, particle size may also reflect comminution during aerial transport, disintegration during sedimentation, dispersal, argillization, and lithification, and grain size may not be a reliable indicator of distance from the volcanic source. Reworking and consequential attrition appear to have been negligible in the case of the Site 403 pyroclasts, for the majority preserve highly angular profiles commonly with delicate cuspate margins. A primary airfall origin seems likely though the ash has been diluted in varying degrees by epiclastic and other constituents; no graded bedding is evident. There is little evidence also of strong bottom currents as indicated by detrital magnetite (Hailwood, this volume) of the currents flowing from southeast to northwest. The clayey matrix of the tuffs originated at least in part through argillization of the glass. Therefore, the overall textures in themselves, may not be reliable guides to depositional energy regimes. The intercalation of tuffs with less-tuffaceous sediment in an overall thickness of 140 meters in the Site 403 lower Eocene indicates sporadic outbursts of vulcanism. The volcanic sources are problematical, as are the degrees of dispersal and compaction of the airfall ash, but the balance of evidence indicates considerable sporadic vulcanism arising at least $100 \mathrm{~km}$ from the two sites. The nearest and most likely source would be the Reykjanes Ridge axis, some $600 \mathrm{~km}$ distant, which was exposed during this time. This may also have been a source of the volcanic glass recorded in lower Eocene sediments from the Hatton-Rockall Basin in DSDP Hole 117A (Laughton, Berggren et al., 1972).

The parental magmas responsible for the lower to mid-Eocene tuffs of Sites 403 and 404 were basaltic to andesite-basaltic with some rhyolite indicated by sparse, unaltered glass shards and feldspar-microlitic particles. Analogy may be drawn with the eruptions of Heckla, Iceland: (1) explosive, producing rhyolitic tephra and (2) mixed andesitic-basaltic tephra and lavas with a highly phreatic initial phase (Thorarinsson, 1971). The silica content of the initial tephra of Heckla attains 62 per cent, a nearly linear function of time, and these eruptions occur after two or more centuries of quiescence.

The Paleocene-Lutetian vulcanism, perhaps originating in the Reykjanes-Iceland province, and recorded by the volcanogenic sediments of the southwest Rockall Plateau margin and Hatton-Rockall Basin, relates to penecontemporaneous vulcanism over an extensive area of northwest Europe and the eastern North Atlantic (Figures 5 and 6). The Paleocene "ash-marker" occurs over 400,000 $\mathrm{km}^{2}$ of the North Sea province (Jacqué and Thouvenin, 1975). Younger Eocene tuffs are locally present in the northern North and in the Scottish embayment. The North Sea tuffs show vertical grading, and pyroclasts ranging from $200 \mu \mathrm{m}$ (at the base of each unit) to $1 \mu \mathrm{m}$ at the top, typifying an ash airfall with little marine sorting. The parent lavas were mainly basaltic with subordinate acid sources (Jacqué and Thouvenin, 1975). Ash was probably derived from the eruptive centers of northwest Britain and its northwestern extensions; the Skagerrak volcanic center spread ash over Denmark and northern Germany (Sharma, 1970). The carbonate-cemented Harwich tuff band (Elliott, 1971), the equivalent of the "ash marker," indicates a basaltic or basaltic-andesitic parentage, but the pyroclasts are highly altered. Montmorillonite-rich layers in the London Clay (Perrin, 1971) of southern Britain afford circumstantial evidence of widespread ash airfall.

The single sample of Quaternary vitroclastic foraminiferal ooze of Site 404 contains abundant fresh glass shards up to $0.3 \times 0.06 \mathrm{~mm}$. These are brown with refractive index $n=$ $1.554 \pm 0.003$, and colorless with $n=1.497 \pm 0.002$, indicating silica contents of 53 and 72 per cent, respectively. They thus indicate two basaltic and rhyolitic parent magmas probably arising from the Reykjanes Ridge, Iceland province, whose vulcanism has spanned at least $55 \mathrm{~m} . \mathrm{y}$.

\section{CONCLUSIONS}

The Paleocene-Lutetian tuffs and tuffaceous samples from Sites 403 and 404 indicate extensive, prolonged though intermittent vulcanism arising probably from the Reykjanes-Iceland province, the Reykjanes Ridge being exposed at this time. The volcanic ash province extended eastwards over the North Sea basin during late Paleocene times following the major magmatic phases of the British Tertiary Igneous province of about 65 to $55 \mathrm{~m}$.y. (Evans et al., 1973), and shortly before the initial separation of Greenland from the Rockall Plateau (about 55 m.y.B.P.) The Site 403 and 404 volcanic samples, therefore, considerably extend the known province of lower Tertiary vulcanism from northwest Europe and Greenland into the northeast Atlantic (Figure 6), relating magmatism to tectonism which preceded and accompanied the major opening of the North Atlantic at about 52 m.y.B.P. The magmatic sources were mainly basalt, perhaps with some andesitic and minor rhyolite input stemming from sporadically phreatic eruptions. The record of vulcanism is obscured by argillization processes and 


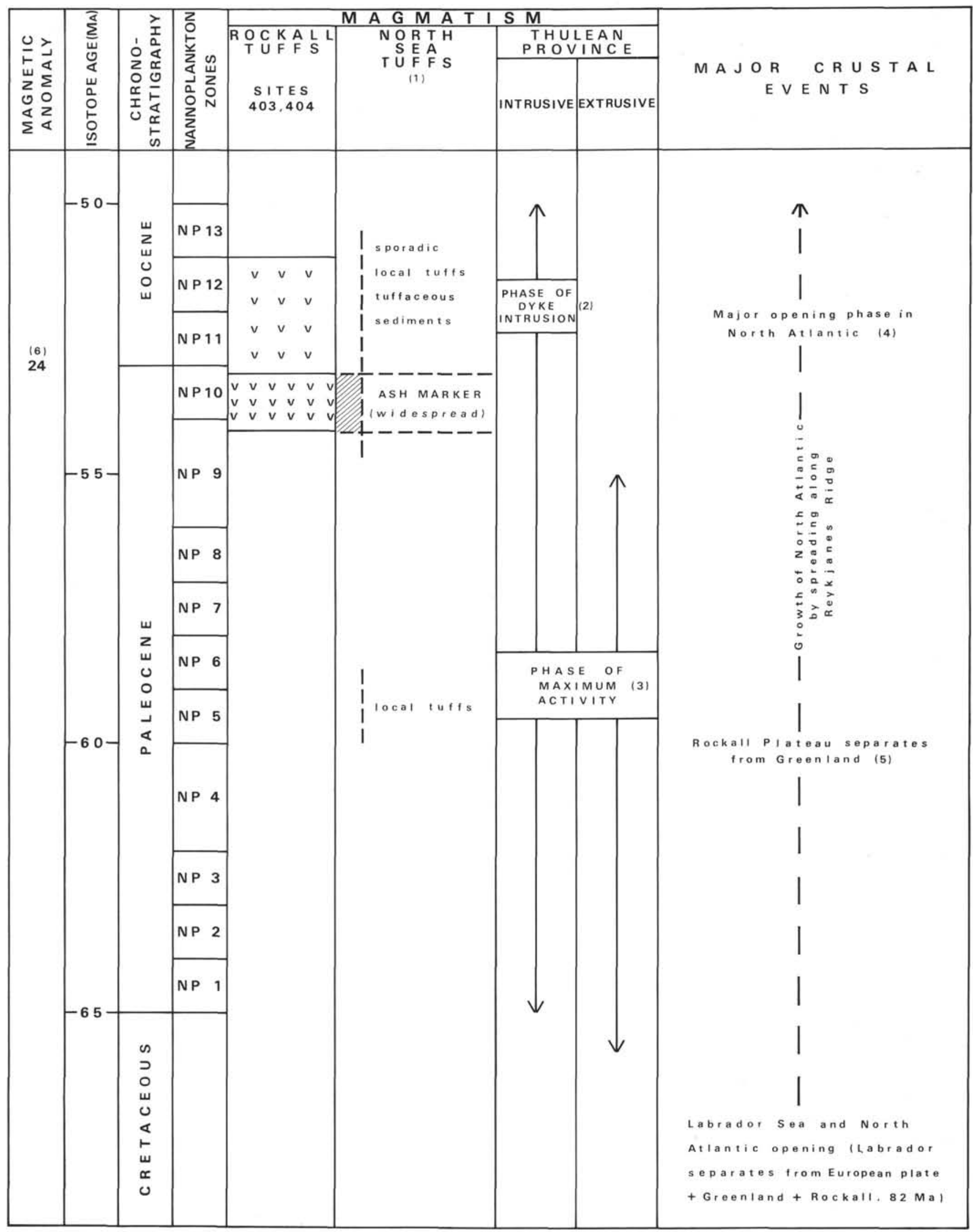

Figure 5. Paleocene-Eocene magmatism in northwest Europe, the North Sea Basins, and the northeast Atlantic. References: (1) Modified after Jacqué and Thouvenin (1975); (2, 3) MacIntyre et al. (1975); (4) Evans et al. (1973); (5) Laughton (1971); (6) Hailwood (this Volume). 


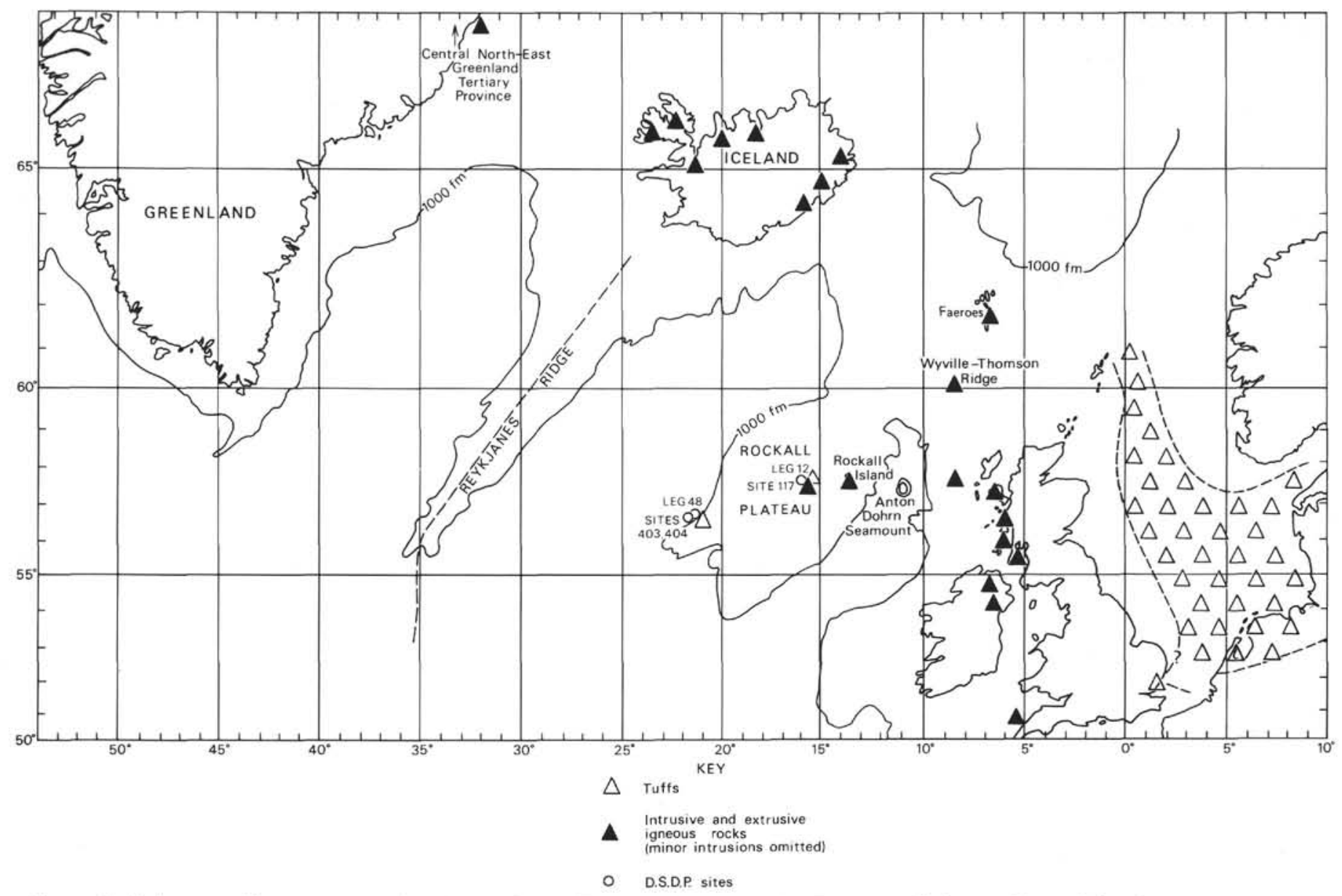

Figure 6. Paleocene-Eocene magmatism in northwest Europe, the North Sea Basins, and the northeast Atlantic.

dilution by terrigenous detritus. The source included high-grade granulites and amphibolites with younger basalts. While argillization of ash makes interpretation of the depositional environments difficult, sporadic higher energy regimes are indicated by oolites and cleaner sandstones, and these may relate to the strong southeast to northwest bottom currents indicated by detrital magnetite (Hailwood, this volume).

\section{ACKNOWLEDGMENTS}

The authors wish to thank Dr. P.A. Sabine and Mr. D.G. Roberts for refereeing this contribution. Apart from the contributors acknowledged in the text, the authors wish also to thank Mr. G.E. Strong for particle-size analyses and glass shard examination. The four chemical analyses (Table 4 ) were by the Laboratory of the Government Chemist, London.

This paper is published by permission of the Director, Institute of Geological Sciences.

\section{REFERENCES}

Bentor, Y.K. and Kastner, M., 1965. Notes on the mineralogy and origin of glauconite, Journal of Sedimentary Petrology, v. 35, p. 155-166.

Biscaye, P.E., 1965. Mineralogy and sedimentation of Recent deep-sea clay in the Atlantic Ocean and adjacent seas and oceans, Bulletin of the Geological Society of America, v. 76, p. 803-832.

Carruthers, J.N., Cole, A.J., and Sollas, W.J., 1923. Notes on some rock fragments dredged up between Faeroe Bank and
Rockall by the Research Vessel S.T. George Bligh during April 1921 , Geological Magazine, v. 60, p. 463-467.

Elliott, G.F., 1971. Eocene volcanics in South-East England, $\mathrm{Na}$ ture Physical Science, London, v. 230, p. 9.

Evans, A.L., Fitch, F.J., and Miller, J.A., 1973. Potassium-argon age determinations on some British Tertiary Igneous rocks, Journal of the Geological Society, v. 129, p. 419-443.

Francis, P., 1976. Volcanoes: Harmondsworth (Penguin Books Ltd.).

Jacqué M. and Thouvenin, J. 1975. Lower Tertiary tuffs and volcanic activity in the North Sea, in Woodland, A.W. (Ed.), Petroleum and the Continental Shelf of North West Europe. London (Applied Science Publishers Ltd.), p. 455-465.

Laughton, A.S., 1971. South Labrador Sea and the evolution of the North Atlantic, Nature, London, v. 232, p. 612-617.

Laughton, A.S., Berggren, W.A., 1972. Initial Reports of the Deep Sea Drilling Project, v. 12: Washington (U.S. Government Printing Office).

Macintyre, R.M., McMenamin, J., and Preston, J., 1975. K-Ar results from Western Ireland and their bearing on the timing and siting of Thulean magmatism, Scottish Journal of Geology, v. 11, p. 227.

Madirazza, I. and Fregerslev, S., 1969. Lower Eocene tuffs at Mønsted, North Jutland, Meddelelser Fra Dansk Geologisk Forening, v. 19, p. 283-310.

Perrin, R.M.S., 1971. The clay mineralogy of British sediments: Mineralogical Society London, p. 247.

Rittenhouse, G., 1943. Transportation and deposition of heavy minerals, Bulletin of the Geological Society of America, v. 54, p. $1725-1780$. 
Roberts, D.G., Matthews, D.H., and Eden, R.A., 1972. Metamorphic rocks from the Southern end of the Rockall Bank, Journal of the Geological Society, v. 128, p. 501-506.

Roberts, D.G., Ardus, D.A., and Dearnley, R., 1973. PreCambrian rocks drilled on the Rockall Bank, Nature, London, $\mathrm{v}$. 244, p. 21-23.

Sabine, P.A., 1972. Preliminary Report on the Basalt. In Laughton, A.S., Berggren, W.A., et al., Initial Reports of the Deep Sea Drilling Project, v. 12: Washington (U.S. Government Printing Office), p. 407-410.

Sharma, P.V., 1970, Geophysical evidence for a buried volcanic mount in the Skaggerak, Meddelelser Fra dansk geologisk Forening, v. 19 , p. 368 .

Thorarinsson, S., 1971. Damage caused by tephra fall in some big Icelandic eruptions and its relation to the thickness of the tephra layers, Acta First International Science Congress on the volcano of Thera, Athens, p. 213-236.

\section{APPENDIX}

Preparation of Thin Sections of Unconsolidated Pyroclastic and Other Sediments From Sites 403 and 404

\section{by C.W. Wheatley}

The majority of volcanogenic sediments from IPOD Leg 48, Sites 403 and 404 were friable or only partly consolidated. Most contained a high proportion of expanding clays and were received in a moist condition. Preparation of thin sections therefore presented some difficulties, particularly since it was necessary to conserve as much material as possible in the undisturbed and uncontaminated state.

The method used was as follows:

1) A slice 4-mm thick was removed by a fretsaw without a lubricant. The relatively coarse teeth of the saw kept the cut free of dust. The more solid specimens were cut by a diamond-impregnated saw with paraffin as lubricant.

2) The resulting slice was carefully placed in a small plastic weighing boat and allowed to dry without disturbance at room temperature. Contraction of the clay content during this process caused some samples to crack into small fragments, but it was possible to keep the pieces in their original relative positions.

3) When the samples were sufficiently dry, epoxy resin (EPO-TEC 301) sufficient just to coat the sample, was poured on. In many cases, the rock was porous enough to allow the resin to soak in thoroughly. To ensure maximum penetration, the boats plus samples were placed in a vacuum chamber to extract remaining air.

4) When the resin had hardened, the encapsulated sample was rigid and coherent and could be treated in the normal manner to produce a thin section. Paraffin was used in all cases to prevent disaggregation of the clay content.

The next stage involved grinding with coarse abrasive and cutting in paraffin (stage 1). At this point, a few of the finer, less-porous specimens were incompletely impregnated with resin. These were dried out and impregnated again.

Disturbing the samples as little as possible until Stage 4 and with paraffin as lubricant, satisfactory thin sections were produced. Cold-setting epoxy resin was used to bond the impregnated sample to the microscope slide, as it was found that even moderate heat caused the samples to buckle. 


\section{PLATE 1}

Photomicrographs of lower Eocene volcanogenic sediments from DSDP Leg 48, Sites 403 and 404.

Figure 1 Pumiceous tuff showing variable compression of vesicles in separate pumice particles. Sample 403-37-1, $47-50 \mathrm{~cm}$ (magnification $40 \times$ ).

Figure 2 Ooliths and pellets of glauconite showing a nucleus of basalt. Sample 403-29-3, 29-32 cm (magnification $160 \times)$.

Figure 3 Nucleus of feldspar-microphyric basalt is enclosed in an oolitic rim of glauconite. Sample 403-29-3, 29-32 $\mathrm{cm}$ (magnification $160 \times$ ).

Figure 4 Reworked glauconitic pumiceous heterolithic tuff showing rounded microlitic lava particles. Sample 404-18-2, 50-52 cm (magnification 40x).

Figure 5 Argillized tuff showing remanent vitroclastic texture. Sample 403-40-1, 46-48 cm (magnification 40x).

Figure 6 Glauconitic pumiceous tuffaceous mudstone. Sample 403-41-1, 111-114 cm (magnification 40×). 
PLATE 1

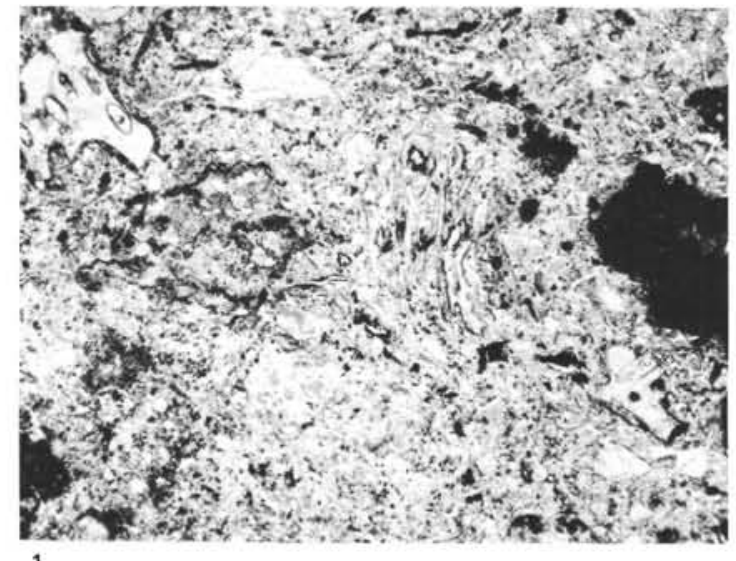

1

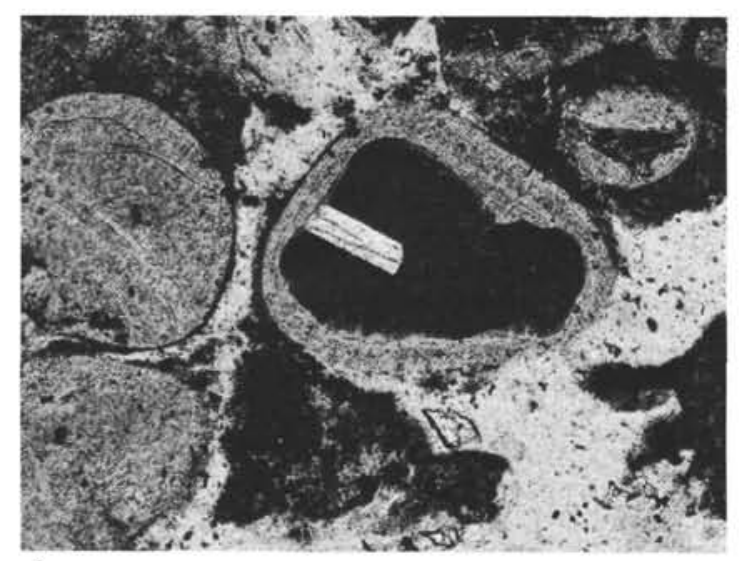

3

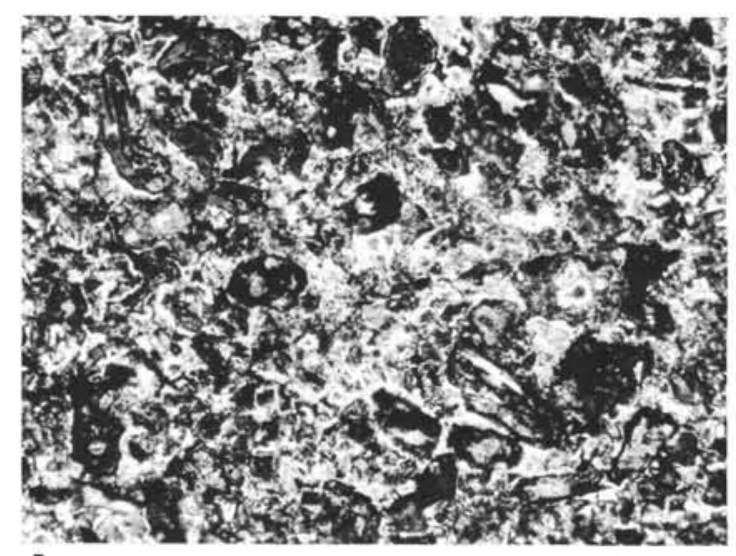

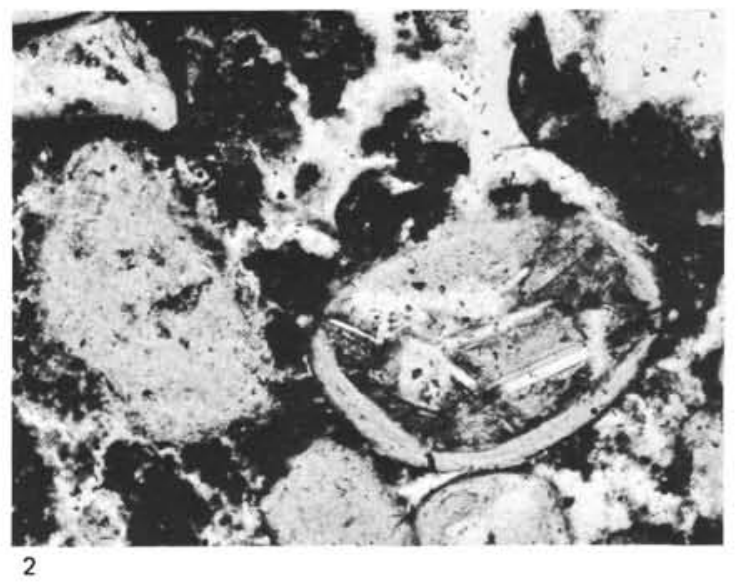
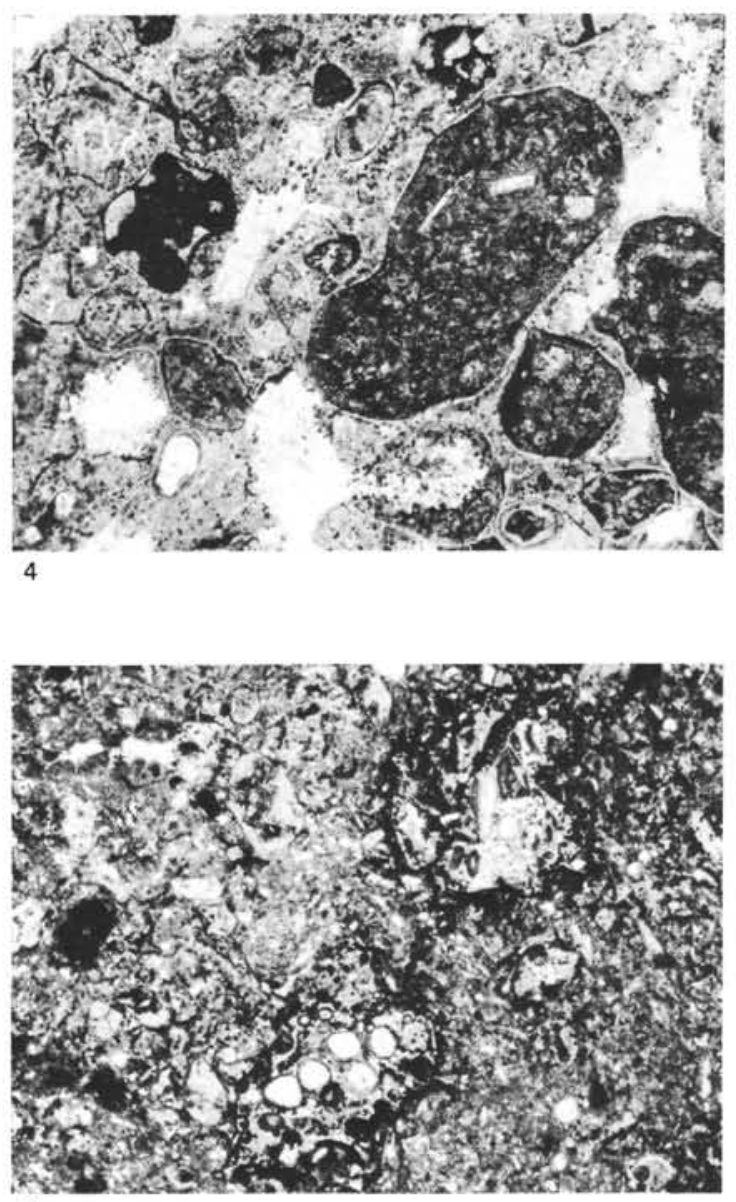